\title{
A STUDY OF FISH LICE (ARGULUS SP.) INFECTION IN FRESHWATER FOOD FISH
}

\author{
Aalberg, K. ${ }^{1}$, Koščová, L. ${ }^{1}$, Šmiga, L. ${ }^{1}$, Košuth, P. ${ }^{1}$ \\ Koščo, J. ${ }^{2}$, Oros, $M .^{3}$, Barčák, D. ${ }^{3}$, Lazar, P. ${ }^{1}$ \\ ${ }^{1}$ Department of Breeding and Diseases of Game and Fish \\ University of Veterinary Medicine and Pharmacy, Komenského 73, 04181 Košice \\ ${ }^{2}$ University of Prešov, Faculty of Human and Natural Sciences, 08001 Prešov \\ ${ }^{3}$ Institute of Parasitology, Slovak Academy of Sciences, Hlinkova 3, 04001 Košice \\ The Slovak Republic \\ lubomir.smiga@uvlf.sk
}

\section{ABSTRACT}

Argulus sp., commonly referred to as fish lice, are crustacean ectoparasites of fishes. The hematophagous parasites attach to and feed off the integument of their hosts. Outbreaks of epizootics have been reported worldwide, causing mass mortalities and having serious economic implications for fish farms and culture efforts. $A r$ gulus fish lice may also serve as vectors of infectious diseases and as intermediate hosts of other parasites. Two native European species, $A$. foliaceus and A. coregoni, as well as the invasive Japanese fish louse $A$. japonicus, have previously been recorded in Slovakia. This study investigated samples collected at fish farms and culture sites of Common carp (Cyprinus carpio L.), Pike-perch (Sander lucioperca $\mathrm{L}$.) and Brook trout (Salvelinus fontinalis M.) in Eastern Slovakia, as well as samples collected from live fish imported to the Slovak Republic. A quantitative description of the of Argulus sp. was recorded from each locality. Samples from Common carp were identified as the invasive A.japonicus, and samples from Pike-perch and Brook trout were identified as A.foliaceus. Evidence of a mixed infection of Pike-perch with both A. foliaceus and A.japonicus was found in samples from Zemplínska Sírava, which was substantiated by electron microscopic examination. Morphometric characteristics were measured and averages and ranges produced for each species and sex.

Key words: Argulus foliaceus; Argulus japonicus; Common carp; crustacean ectoparasites; Pike-perch; mixed parasite infection

\section{INTRODUCTION}

Fish lice is common name for branchiurid ectoparasites of fish from the genus Argulus [11]. Although Argulus fish lice are widely distributed and able to parasitize and thrive off a wide range of host species, argulosis have rarely been found to have severe effects on naturally occurring fish populations $[5,27]$. Here the low intensity of infection is typically insufficient to be associated with mortality or extensive tissue damage [10]. This occurs as a result of a com- 
bination of the mechanical action of the attachment organs and the feeding apparatus of the argulid, and the chemical action of enzymes or toxins injected into the host fish by the feeding fish louse [31]. Primary lesions develop at the predilection sites; haemorrhagic spots may be seen on the fins and at the base of fins, the head, and non-respiratory surfaces of the gill cavity [5]. Argulosis may lead to secondary infections, have also been linked to the transmission of infectious and other parasitic disease $[6,31]$.

Argulosis typically occurs on fish farms, where high stocking densities facilitate parasite transmission, while factors such as overcrowding, capture, handling and confinement may act as stressors and negatively influence the host immune response [31].

The fish lice have a direct life cycle. After mating the female will leave the host fish and deposit eggs on solid surfaces in the immediate environment [31]. Occurrence of argulosis is seasonally dependent, parasites typically reach peak abundance during summer and autumn [10].

In Europe we can only find three species of Argulus parasitizing freshwater fishes, namely the native $A$. foliaceus and $A$. coregoni, and the invasive and now widely spread $A$. japonicus [10, 31]. Other European species of Argulus have been found on marine fishes [10,21].

This study addresses the lack of knowledge of the present situation of these parasites in economically important species of fish in Slovakia. Three species have previously been recorded in Slovakia, A. foliaceus, A. coregoni and the invasive Japanese fish louse, $A$. japonicus [9].

\section{MATERIAL AND METHODS}

Common carps (Cyprinus carpio L.; Cypriniformes) and pike-perches (Sander lucioperca L.; Perciformes) were sampled from commercial culture ponds in Eastern Slovakia, and from live fish imported from the Czech Republic and Hungary. Brook trout (Salvelinus fontinalis M., Salmoniformes) was sampled from a small culture pond in Košice. In the time period 2013-2015 a total of 116 Common carps, 40 Pike-perches and 2 Brook trouts were dissected.

The fishes were dissected and examined as a part of routine screening during storage or harvesting, or as a part of a diagnostic procedure on fishes displaying clinical signs of disease. A complete parasitological dissection was performed, and age category, sex, standard length and body weight was noted in the dissection protocol. The Argulus sp. fish lice were collected using forceps, and fixed in $4 \%$ formalin or $70 \%$ ethanol. Parasitological indices, such as prevalence $(P$; the number of hosts infected with 1 or more individuals of a particular parasite species, divided by the number of hosts examined for that parasite species), intensity of infection (ii; the number of individuals of a particular parasite species in a single infected host) and mean intensity (mi; the average intensity of a particular species of parasite among the infected members of a particular host species), and mean abundance (ma; the total number of individuals of a particular parasite species in a sample of a particular host species divided by the total number of hosts of that species examined) [1], were evaluated.

Examination of specimens was carried out using a stereomicroscope. Species determination was performed as described by previous authors [2, 22]. Morphometric mesurements were taken on the fixed specimens.

\section{RESULTS}

\section{Species determination of Argulus sp.}

The investigated specimens of Argulus sp. were identified as $A$. foliaceus and A. japonicus. The fish lice obtained from Common carp was identified as A.japonicus and from Pike-perches both $A$. foliaceus and $A$. japonicus were identified. Mixed infection with both $A$. foliaceus and $A$. japonicas was observed in Pike-perches from Zemplínska Š́rava. The fish lice collected from Brook trout was identified as A.foliaceus, some specimens had a body length and underdeveloped second maxillae consistent with the fifth developmental stage (Table 1).

Table 1. The species of genus Argulus found infecting carp (Cyprinus carpio L), Pike-perch (Sander lucioperca L.) and Brook trout (Salvelinus fontinalis M.)

\begin{tabular}{ccc}
\hline Host species & Species of Argulus & Sampled locality \\
\hline Common carp & A. japonicus & $\begin{array}{c}\text { Hrhov, Perín, Import } \\
\text { from Czech Republic }\end{array}$ \\
Pike-perch & A. foliaceus & $\begin{array}{c}\text { Pal'kov-Lúčky, } \\
\text { Zálužice-Lúčky, } \\
\text { Bátovce }\end{array}$ \\
A. foliaceus and & Zemplínska Šírava \\
\hline Brook trout & A. foliaceus & $\begin{array}{c}\text { Botanical garden } \\
\text { in Košice }\end{array}$ \\
\hline
\end{tabular}


Table 2. A quantitative assessment of the parasite populations found on carp (Cyprinus carpio L.)

\begin{tabular}{ccccc}
\hline Locality & $\begin{array}{c}\mathbf{P} \\
{[\%]}\end{array}$ & $\mathbf{~ m i}$ & $\mathbf{i i}$ & $\mathbf{M a}$ \\
\hline $\begin{array}{c}\text { Hrhov } \\
\text { (Winter) }\end{array}$ & 11.1 & 3 & 3 & 0.33 \\
$\begin{array}{c}\text { Hrhov } \\
\text { (Harvest) }\end{array}$ & 38.5 & 19.6 & 7.30 & 7.54 \\
$\begin{array}{c}\text { Perin } \\
\text { Import }\end{array}$ & 6.3 & 9 & 9 & 0.56 \\
from Czechia & 19.4 & 2 & 1,3 & 0.39 \\
$\begin{array}{c}\text { Import } \\
\text { from Hungary }\end{array}$ & 8.7 & 3 & 3 & 0.26 \\
\hline
\end{tabular}

$\mathrm{P}$ - prevalence; ii - intensity of infection

mi — mean intensity; ma — mean abundance
Table 3. A quantitative assessment of the parasite populations found on Pike-perch (Sander lucioperca L.)

\begin{tabular}{ccccc}
\hline Locality & $\begin{array}{c}\mathbf{P} \\
{[\%]}\end{array}$ & $\mathbf{m i}$ & $\mathbf{i i}$ & $\mathbf{m a}$ \\
\hline $\begin{array}{c}\text { Pal'kov-Lúčky } \\
\text { Zálužice-Lúčky }\end{array}$ & 100 & 80.3 & $40-144$ & 80.3 \\
Bátovce & 100 & 32 & $17-53$ & 32 \\
Zemplínska Šírava & 100 & 10.2 & 6.14 & 10.2 \\
\hline
\end{tabular}

$\mathrm{P}$ - prevalence; ii - intensity of infection mi - mean intensity; ma - mean abundance

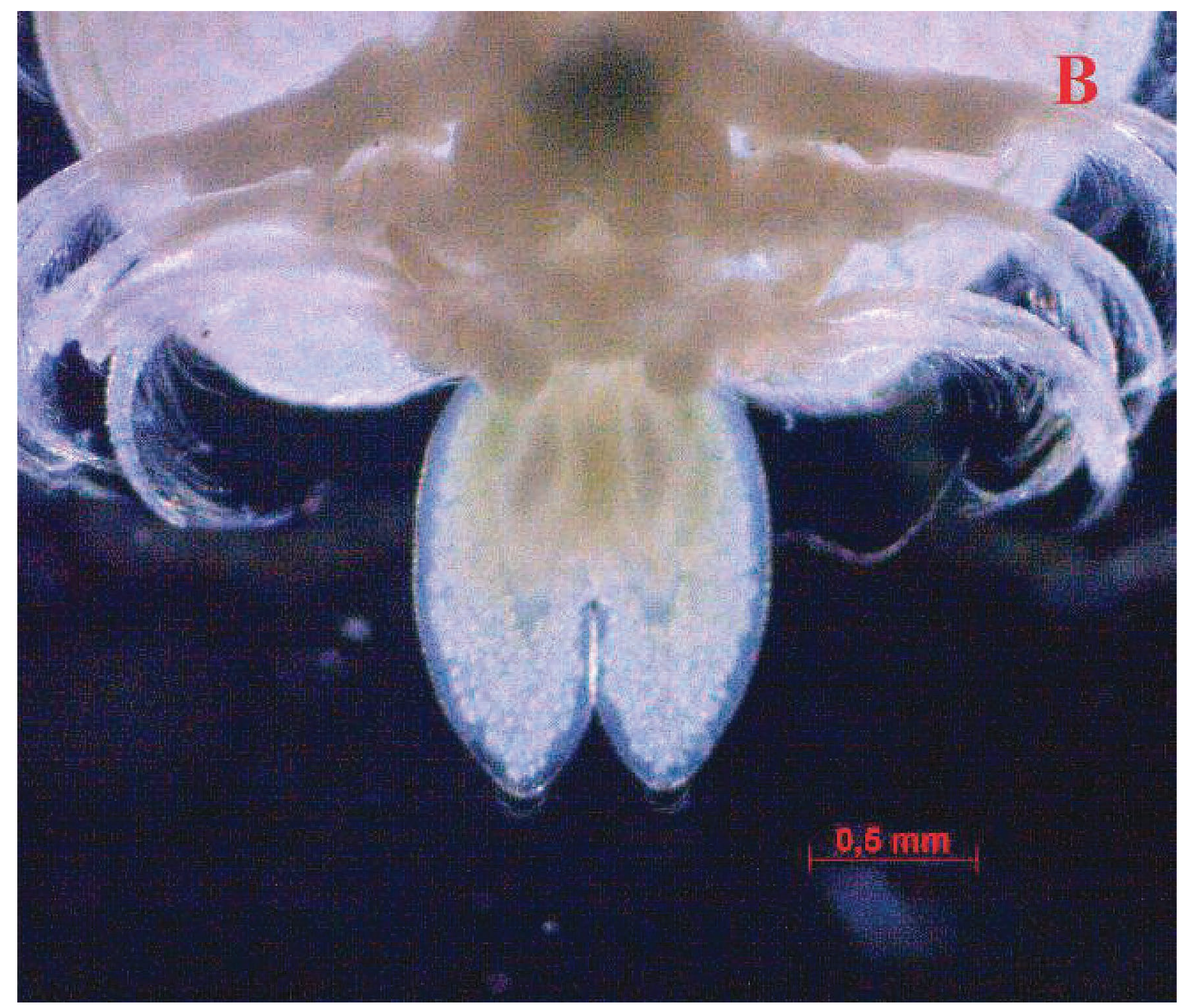

Fig. 1. Microscopic examination of Argulus japonicus

(A) - male on the right, female on the left, $0,8 \times$ mangnification by stereomicroscope

(B) - abdominal lobes of male. Magn. $\times 2.0$ (stereomicroscope) 


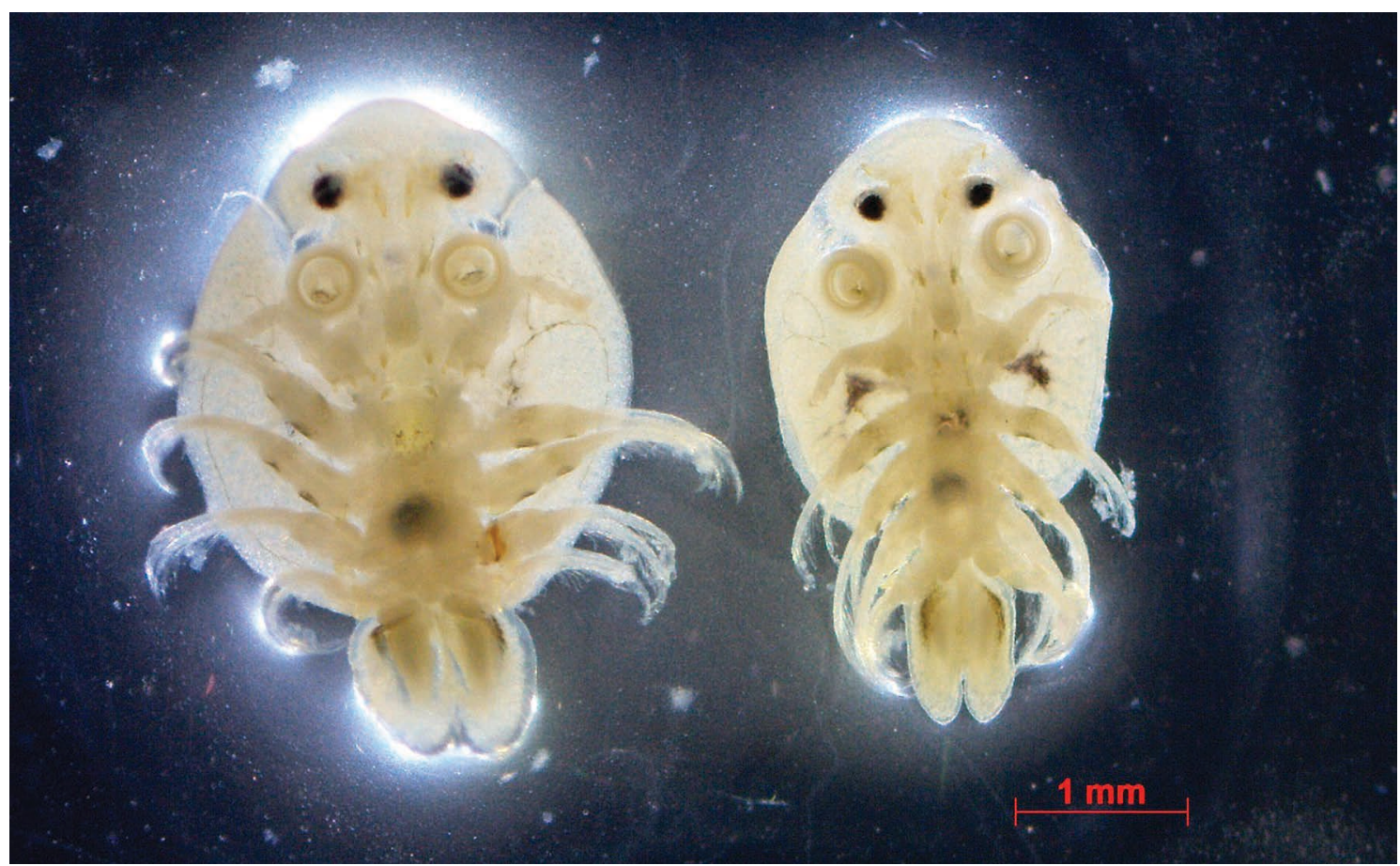

Fig. 2. Microscopic examination of males of two species: Argulus japonicus (left side) and $A$. foliaceus (right side) Magn. $\times 0.8$ (stereomicroscope)

\section{Parasite populations found at sampled localities}

The prevalence of Argulus infection recorded from carp varied among the sampled localities, ranging from $6.3 \%$ to $38.5 \%$. The highest recorded prevalence of infection in carp was found in the pond Hrhov in the harvesting period (Table 2).

The prevalence in Pike-perch was very high, ranging from $80 \%$ to $100 \%$ in the sampled localities (Table 3 ).

Prevalence of $A$. foliaceus in Brook trout was $100 \%$ with infection intensities ranged 25-30 and mean intensity of infection was 30 specimens per fish and mean abundance 30.

\section{DISCUSSION}

\section{Species determination of Argulus sp.}

The investigated specimens of Argulus sp. fish lice were identified as A. foliaceus, and A. japonicus.

The fish lice obtained from carp was identified as $A$. japonicus. All three European Argulus species have previously been recorded from carp in Slovakia [10], but only the
Japanese fish louse was identified from the sampled localities. Carp infections with $A$. japonicus have been described in several studies $[16,19,30]$.

In the fish lice samples obtained from Pike-perches both $A$. foliaceus and A. japonicus was identified. All three of the European Argulus species have previously been recorded from Pike-perch in Slovakia [9], but A. coregoni was not found among the fish lice specimens. Perchid fishes are preferred hosts of A. foliaceus [23], and Pike-perch infection with $A$. foliaceus have been described by previous authors $[14,32]$.

In three of the sampled Pike-perch localities only $A$. foliaceus was present, while a mixed infection with both $A$. foliaceus and A. japonicas was observed in Pike-perches from Zemplínska Šírava. Several cases of mixed Argulus sp. infections have been described, however the mixed infections in question involved different Argulus species and host fishes from our findings in Zemplínska Šírava $[4,8,20]$.

Morphologically the two species $A$. foliaceus and A. japonicus are very similar $[19,22]$, and it may be impossible to determine the species of certain specimens [22]. Fish lice from Zemplínska Šŕrava had several characteristics consis- 
tent with $A$. japonicus, however these traits are subject to variation [3]. Measurements of morphometric characteristics were found to be in range with findings of other authors [13, 18, 26, 28].

The fish lice collected from Brook trout was identified as A. foliaceus. Infection of Brook trout with Argulus sp. has not been previously recorded from Slovakia [9], however fish lice infection in this fish species have been recorded by other authors $[3,7]$. A. foliaceus been found to infect other salmonid fish species $[3,12]$.

A. foliaceus from Brook trout was found to be significantly smaller than specimens obtained from Pike-perches, their body length was consistent with the sixth and seventh developmental stage [18]. Some specimens had a body length and underdeveloped second maxillae consistent with the fifth developmental stage [18].

\section{Quantitative description of Argulus sp.}

The prevalence of Argulus infection recorded from carp varied among the sampled localities, ranging from $6.3 \%$ to $38.5 \%$.

The highest recorded prevalence of infection in carp was found in Hrhov in the harvesting period, greatly exceeding the prevalence from the same location during screening before and after wintering. This concurs with findings in other studies, where Argulus populations typically reach peak abundance during summer and autumn $[6,17]$.

The prevalence of infection in Pike-perch was very high, ranging from $80 \%$ to $100 \%$ in the sampled localities. Samples were collected in the summer and autumn, the period in which peak abundance is expected $[6,17]$.

The prevalence, mean intensity and abundance of Argulus sp. was higher in Pike-perches compared to Carp. Pikeperches are gregorious animals, where occurring in shoals may facilitate parasite transmission [29], however conflicting evidence of the effect of shoaling on Argulus infection exist [15]. The Zemplínska Šŕrava watercourse is one of the most severely PCB contaminated sites in Europe, and high levels of PCBs have been found in Pike-perches from this location previously [25]. PCBs have an immunosuppressive effect on fish and a positive correlation between PCB (polychlorinated biphenyl) pollution and abundance of ectoparasites in fish have been established [24].

The prevalence of infection in Brook trout was very high, samples were collected in the summer and autumn, the period in which peak abundance is expected $[7,26]$.

\section{CONCLUSION}

This study deals with Argulus fish lice infections of freshwater food fishes. Argulus fish lice are branchiurid ectoparasites capable of inflicting serious pathological effects on freshwater fishes. Little is known on the present status of fish lice in freshwater food fish in Slovakia. This study has shown that Argulus sp. are found parasitizing economically important species of fish in Slovakia, determined the species of fish lice are present and which species of fish they infect, and described the parasite populations found on infected fish species.

\section{ACKNOWLEDGEMENT}

The study was supported by Vega projects No. 1/0916/14, 1/0918/17 and 1/0916/17.

\section{REFERENCES}

1. Bush, A. O., 1997: Parasitology meets ecology on its own terms: Margolis et al. revisited. J. Parasitol., 83, 575-583.

2. Bykhovskaya-Pavlovskaya, I. E. et al., 1964: Key to Parasites of Freshwater Fishes of the USSR. Israeli Program for Scientific Translations, Jerusalem, 694 pp.

3. Frimeth, J.P., 1987: A survey of the parasites of nonanadromous and anadromous brook charr (Salvelinus fontinalis) in the Tabusintac River, New Brunswick, Canada. Canadian Journal of Zoology, 65, 1354-1362.

4. Jafri, S.I.H., Ahmed, S. S., 1994: Some observations on mortality in major carps due to fish lice and their chemical control. Pakistan Journal of Zoology, 26, 274-276.

5. Kearn, G.C., 2007: The Common fish louse - Argulus. In Leeches, Lice and Lampreys: A Natural History of Skin and Gill Parasites of Fishes. Dordrecht, The Netherlands, Springer, $237-264$.

6. Lester, R. J. G., Hayward, C. J., 2006: Phylum Arthropoda. In Fish Diseases and Disorders. Volume 1: Protozoan and metazoan infections, 2nd edn., UK, King's Lynn, 466-565.

7. Menezes, J., 1990: Rainbow trout culture failure in a small lake as a result of massive parasitosis related to careless fish introductions. Aquaculture, 89, 123-126.

8. Mikheev, V.N., Pasternak, A.F., Valtonen, E.T., Lankinen, Y., 2001: Spatial distribution and hatching of overwintered 
eggs of a fish ectoparasite, Argulus coregoni (Crustacea: Branchiura). Diseases of Aquatic Organisms, 46, 123-128.

9. Moravec, F., 2001: Checklist of the Metazoan Parasites of Fishes of the Czech Republic and the Slovak Republic (1873-2000). Prague, Academia, 168 pp.

10. Møller, O.S., 2012: Argulus foliaceus. In Fish Parasites: Pathobiology and Protection, Oxfordshire, UK, CABI, 337-346.

11. Noga, E. J., 2010: Fish Diseases: Diagnosis and Treatment. Singapore, Willey-Blackwell, 2nd edn., 536 pp.

12. Northcott, S. J., Lyndon, A.R., Campbell, A.D., 1997: An outbreak of freshwater fish lice, Argulus foliaceus L., seriously affecting a Scottish stillwater fishery. Fish. Manag. Ecol., 4, 73-75.

13. Pasternak, A.F., Mikheev, V.N., Valtonen, E.T., 2000: Life history characteristics of Argulus foliaceus L. (Crustacea: Branchiura) populations in Central Finland. Annales Zoologici Fennici, 37, 25-35.

14. Pazooki, J., Masoumian, M., Yahyazadeh, M., Abbasi, J., 2007: Metazoan parasites from freshwater fishes of northwest Iran. Journal of Agricultural Science and Technology, 9, 25-33.

15. Poulin, R., 1999: Parasitism and shoal size in juvenile Sticklebacks: Conflicting selection pressures from different ectoparasites? Ethology, 105, 959-968.

16. Rahman, M., 1996: Effects of a freshwater fish parasite, Argulus foliaceus Linn. infection on common carp, Cyprinus carpio Linn. Bangladesh Journal of Zoology, 24, 57-63.

17. Rohlenová, K., Morand, S., Hyršl, P., Tolarová, S., Flajšhans, M., Šimková, A., 2011: Are fish immune systems really affected by parasites? An immunoecological study of common carp (Cyprinus carpio). Parasites and Vectors, 4, 120.

18. Rushton-Mellor, S. K., 1992: Discovery of the fish louse, Argulus japonicus Thiele (Crustacea: Branchiura), in Britain. Aquacult. Res., 23, 269-271.

19. Rushton-Mellor, S. K., Boxshall, G. A., 1994: The development sequence of Argulus foliaceus (Crustacea: Branchiura). Journal of Natural History, 28, 763-785.

20. Sahoo, P., Hemaprasanth, K., Kar, B., Garnayak, S. K., Mohanty, J., 2012: Mixed infection of Argulus japonicus and Argulus siamensis (Branchiura, Argulidae) in carps (Pisces, Cyprinidae): loss estimation and a comparative invasive pattern study. Crustaceana, 85, 1449-1462.

21. Schram, T. A., Iversen, L., 2005: Argulus sp. (Crustacea: Branchiura) on cod, Gadus morhua from Finmark, northern Norway. J. Mar. Biol. Assoc. UK, 85, 81-86.

22. Soes, D. M., Walker, P. D., Kruijt, D. B., 2010: The Japanese fish louse Argulus japonicus new for The Netherlands. Lauterbornia, 70, 11-17.
23. Suárez-Morales, E., 2015: Chapter 29 - Class Maxillopoda. In James, H., Thorp, D., Rogers, Ch. (Eds.): Thorp and Covich's Freshwater Invertebrates, 4th edn., Boston, Academic Press, 709-755.

24. Sures, B., 2005: Effects of pollution on parasites, and use of parasites in pollution monitoring. In Marine Parasitology, Oxon, UK, Csiro Publishing. Available at http://www.parasitejournal.org or http://dx.doi.org/10.1051/parasite/2008153434.

25. Sures, B., Knopf, K., 2004: Individual and combined effects of cadmium and 3,3,4,4,5-pentachlorobiphenyl (PCB 126) on the humoral immune response in European eel (Anguilla anguilla) experimentally infected with larvae of Anguillicola crassus (Nematoda). Parasitology, 128, 445-454.

26. Swanepoel, J.H., Avenant-Oldewage, A., 1992: Comments on the morphology of the pre-oral spine in Argulus (Crustacea: Branchiura). J. Morphol., 212, 155-162.

27. Taylor, N.G.H., Sommerville, C., Wootten, R., 2005: A review of Argulus sp. occurring in UK freshwaters. Bristol, UK, Environment Agency, 30 pp.

28. Wadeh, H., Yang, J. W., Li, G. Q., 2007: Ultrastructure of Argulus japonicus Thiele, 1900 (Crustacea: Branchiura) collected from Guangdong, China. Parasitol. Res., 102, 765-770.

29. Walker, P.D., Harris, J.E., Van der Velde, G., Bonga, S.E.W., 2008: Differential host utilisation by different life history stages of the fish ectoparasite Argulus foliaceus (Crustacea: Branchiura). Folia Parasitol., 55, 141-149.

30. Walker, P. D., Russon, I. J., Haond, Ch., Bonga, S. E. W., 2011: Feeding in adult Argulus Japonicus Thiele, 1900 (maxillopoda, Branchiura), an ectoparasite on fish. Crustaceana, 84, $307-318$.

31. Walker, P. D., Flik, G., Bonga, S. E. W., 2004: The biology of parasites from the genus Argulus and a review of the interactions with its host. In Host-Parasite Interactions. Hampshire, UK, Taylor and Francis, 110-135.

32. Žiliukiene, V., Žiliukas, V., Stankus, S., 2012: Infestation of Argulusfoliaceus L. on fish fry reared in illuminated cages. Vet. Med. Zoot., 57, 83-88.

Selected paper from the 59th STUDENT SCIENTIFIC CONFERENCE, Section III - Food hygiene and the environment, held at the University of Veterinary Medicine and Pharmacy in Košice, SR, on April 6, 2016. 